DOI https://doi.org/10.36059/978-966-397-113-1/262-283

\title{
CRITICISM AS A CONCEPT OF CLASSICAL SCIENCE AND A SOCIAL PHENOMENON OF CIVIL SOCIETY: THE POTENTIAL OF CONSTITUTIONAL AND INTERNATIONAL LAW (AS EXEMPLIFIED BY THE UKRAINIAN SOCIETY)
}

\section{Nediukha M. P.}

\section{INTRODUCTION}

The topicality of scientific criticism is conditioned by a number of circumstances: a) by its status as a scientific and educational paradigm, an immanent means of developing scientific knowledge, a manifestation of academic freedom and creative activity as well as by everyday circumstances of society's life. Lack of freedom of criticism negatively affects, first of all, the theoretical and heuristic potential of science, leads to its stagnation, generates the threat of its degeneration into dogma, utopia. Public crises, social disasters have as one of their underlying causes, as is known, the neglect of the possibilities of scientific criticism as a means of ensuring a public dialogue between the authorities and the people, the rule of law and civil society; b) by the necessity of creating the space of public scientific and information communication, the transition from the paradigm of reproduction of knowledge to the paradigm of the formation of the capacity for independent creativity, creative, innovative activity; c) by its ability to integrate science, education and innovative activities / production as the dominant regularity of the development of a «knowledge society»; d) by ensuring the competitiveness of science and the profession of scientist; e) by being an effective means of limiting / eliminating the threats of subjectivism and voluntarism in the process of cognition, of avoiding dissent charges, of neutralizing the threats of the use of repression against scientists, etc. As an example of the latter, one may consider, in particular, the campaigns officially declared by the Soviet authorities to «combat bourgeois pseudoscientists»- sociology, political science, general theory of systems, genetics, cybernetics, mathematical logic, the theory of relativity, etc. - which was fairly qualified as manifestations of the scientific inquisition of the Middle Ages 
and the New Time (processes against J. Bruno, N. Copernicus, G. Galilei, etc.); e) by the tasks of forming personal and professional competence.

A human being, being a personality, a biosocial being as the supreme creation of God, is gifted, as is known, with a special ability - critical thinking as a natural ability to respond to the world of ideas, value orientations and beliefs, circumstances of everyday life by expressing his attitude - rational or emotional, constructive or destructive, ironic or satirical, high or low, etc. The above is achieved, as it is generally known, by means of arguments and counter-arguments, objections and assertions and their organic combination in the process of deploying a discussion or polemics, as well as by formulating conclusions (inferences) as definitive, recognized by the scientific community for a certain period of time, results of research as true or vice versa - false, subjectivist, controversial, destructive. Accordingly, in the latter case, the attitude of a human being toward a human being as subjects of social interaction can acquire deformed features - both in the essential and functional, goal attainment characteristics - then scientific criticism turns into its oppositefaultfinding, thus replenishing not the research arsenal of science, but the methods of eclecticism, sophistry, manipulative influence on the consciousness of man, public opinion that distort the truth, generates states of information, psychological, or hybrid war, leads to hidden actions of real aggression, annexation of a part of the territory of a sovereign state, thereby imposing on the international community threatening scenarios of returning to the policy of conflict and force confrontation.

Unfortunately, the problematics of critical thinking can hardly be considered developed: the terms «scientific criticism», «critical thinking», «constructive criticism», «faultfinding», etc, are groundlessly absent in domestic encyclopedias and dictionaries, monographic studies. In the educational-methodical literature, the content of the aforementioned fundamental concepts of science is reduced mainly to the search, detection, and correction of logical errors of the process of proving or refuting one or another thesis, judgment, reasoning, etc, which is equivalent to substituting the meaning of the term «error» for the term «criticism». Accordingly, according to the latter methodological approach, criticism is often regarded as theoretical conceptualization and methodical / technological guidance 
for finding an error and correcting it (a formal-logical operation), with which one can hardly agree.

\section{The essence and purpose of scientific criticism / critical thinking}

Critical thinking is, as we know, a multiple-meaning term used in various spheres of society's life, while being one of the defining attributive characteristics of man as a biosocial being, as the supreme creation of the Cosmos. Accordingly, scientific criticism is: 1) a notion of science; 2) individual or collective social action, an everyday attribute of human life; 3) the unity of word and action in the legitimate social space legal, intellectual, economic, entrepreneurial one, etc. as an established, civilized way of responding to events, facts and processes, and various manifestations of the modern world. Scientific criticism implies unconditional recognition of the right of the other to exist as a selfsufficient subject (a person, a social or political organization, etc), an equal party in a dialogue or polemics, the presence of an interested partner or a known opponent, etc. In this sense, the essential content and functional purpose of scientific criticism is determined by the content of the principle «when you criticize, propose; when you propose, act.».

Criticism, being a notion of classical science, can be defined as an effective polemical means to overcome the limitedness of a publicly expressed point of view, published theoretical constructs, starting with a separate judgment (definition) and up to the clarification of the essence of concepts, doctrines, or theories by bringing forward and properly substantiating a constructive alternative as a kind of variant of finding the truth, or at least a satisfactory answer to the question of the opponent ${ }^{1}$.

Criticism is also defined as «one of the important methods of scientific knowledge, aimed at testing any scientific judgments and knowledge systems and disposing of them in the event of their inconsistency with established cognitive criteria and standards. The latter include, in particular, the principles of objectivity, truth, provenness, universality, utility» ${ }^{2}$. Criticism as a scientific term is also used by

\footnotetext{
Недюха М. П. Критика як теоретико-пізнавальний та діалогово-полемічний конструкт конституційно-правового мислення // II Всеукраїнські правові наукові читання пам'яті доктора юридичних наук, професора, заслуженого юриста України, член-кореспондента Національної академії правових наук України Ніни Романівни Нижник: збірник матеріалів / за заг. ред. А. Є. Шевченка. Вінниця: ТОВ “ТВОРИ”, 2018. 180 с.

2 Лебедев С. А. Философия науки : краткая энциклопедия (основные направления, концепции, категории). М.: Академический проект, 2008. 692 с.
} 
representatives of non-classical and post-nonclassical science, the main content, functional, and target-orienting features of which are seen in the positioning of the subject of action and the construction of the appropriate space - social, legal, political, civil one, etc.

Creators of criticism as a kind of paradigm of scientific research, its classics are philosophers of Ancient Greece and Ancient Rome, who in dialogue form developed ideas about the nature, essence, rootedness of law in the objective and subjective nature of things, in the eternal order of the structure of the universe with its subordination to the flow of time and the immutable human nature (Democritus, Anaxagoras, Socrates, Epicurus, Protagoras, Plato, Gorgias, Prodiquus, Antiphonus, Aristotle, etc.).

German philosopher A. Schopenhauer (1788-1860) first synthesized techniques of polemics, singled out the errors of thought, polemics as a public event ${ }^{3}$.

The philosophy of I. Kant (1724-1804) is commonly categorized, as it is known, into two periods - the «pre-critical» (until 1770) and the «critical» ones. In his major works of the «critical» period - Critique of Pure Reason (1781), Critique of Practical Mind (1788) and Criticism of the Judgment Capacity (1790), the cognitive capabilities of man, the source and potential of scientific thought, knowledge, and faith, of «categorical imperative» as a moral obligation and a universal principle of social behavior are thoroughly investigated. The creative precept of I. Kant is that «philosophical research should be based... on a critical study of the cognitive capabilities of man, as well as of the boundaries to which knowledge is directed $\rangle^{4}$.

Peter Struve (1870-1944) and E. Bernstein (1850-1932) are known, first of all, as consistent critics, systemic opponents of Marxism with its theory of revolutionary overcoming of the historical contradiction between the determinism of capitalism and the voluntarism of the proletariat.

Peter Struve noted, in particular, that Marxism combines both scientific realism and elements of utopia, fatalism, and radical pragmatism. Seeing P. Struve's views as the greatest threat to the spread of the doctrine of K. Marx in the Russian Empire, V. Lenin, as it is well known, devoted to the analysis of the theoretical positions of his opponent one of his first works «The Economic Content of Populism (Narodnik

\footnotetext{
${ }^{3}$ Шопенгауэр А. Эристика, или искусство побеждать в споре. СПб.: 1900.

${ }^{4}$ Асмус В. Ф. Иммануил Кант. М.: “Наука”, 1973. 534 с.
} 
Movement) and Its Criticism in Struve's Book (Reflection of Marxism in Bourgeois Literature)" in connection with the book by P. Struve "Critical Notes on the Question of Economic Development of Russia» (1984), which, however, only contributed to the popularization of P. Struve's views as a theorist of «legal Marxism», a systemic critic of Marxism.

Eduard Bernstein, being the author of the famous credo «The ultimate goal is nothing, but the movement (to it) is everything», called into question the fundamentals of Marxism with its communism, the dictatorship of the proletariat, and the leading role of the party vanguard of workers, refuted the theses of the drop in profit rate in connection with the process of capital accumulation, of the destruction of the middle class and the death of capitalism, of the expediency of total nationalization and central planning, substantiated the starting points of the theory of social state, etc ${ }^{5}$. It is noteworthy that the ideas expressed by E. Bernstein were further developed in scientific works of Peter Struve, Nikolai Berdyaev, Sergei Bulgakov, Bohdan Kystyakivskyi, Mykhaylo Tuhan-Baranovskyi, etc, as well as were confirmed by the practice of social changes of the twentieth century, by the facts of the everyday reality of the modern world.

Karl Popper saw in Marxism a form of manifestation of «methodological collectivism»- the all-encompassing influence of the state, class, ideas on the course of historical and social processes and the consideration of man as a means of achieving the goals set. Instead, the ideal of social reformation of society should be represented by a democratic, «open» society, which establishes human rights and freedoms through their institutionalization ${ }^{6}$.

Systemic critics of Marxism also include T. Adorno, R. Aron, M. Weber, J. Habermas, R. Garaudy, M. Horkheimer, M. Dilas, S. Carillo, L. Kolakowski, G. Lukacs, H. Marcuse etc.). For example, $\mathrm{J}$. Habermas quite rightly views democracy as a means and real practice of achieving rational and open consensus in the process of developing and adopting decisions.

\footnotetext{
${ }^{5}$ Бернштейн Э. Воспоминания: Социал-демократические годы учения. В годы моего изгнания. К.: Основні цінності, 2005. 328 с.

${ }^{6}$ Поппер Карл. Открытое общество и его враги. Т.1: Чары Платона. Пер. с англ. под ред. В. Н. Садовского. М.: Феникс, Международный фонд “Культурная инициатива", 1992. 448 с.; Т. 2: Время лжепророков: Гегель, Маркс и другие оракулы. М.: Феникс, Международный фонд "Культурная инициатива", 1992. 528 с.
} 
Critical rationalism (K. Popper, Lakatos, Feyerabend) considers that the criterion of truth is not proving and confirming knowledge, but rather its refuting by means of turning to empirical situations, presupposes criticism of both one's own arguments and arguments of the opponent, analysis of counterarguments and also considers it fundamentally possible to change one's views in accordance with the arguments presented in the discussion process ${ }^{7}$.

The highest form of criticism is self-criticism. It is no coincidence that French philosopher of the XX century Michel Foucault defined criticism as a means, a system for evaluating oneself, one's own actions, both mental (spiritual) and physical.

Characteristic features of constructive criticism include: a) meaningful certainty and functional purpose, according to which criticism is a way of cognizing reality in terms of approaching the truth, its formulation and further deepening, and also a means to overcome the limitedness of a scientific viewpoint (a point of view, a conception, a theory) for the sake of assertion of completeness / comprehensiveness of the truth, for the sake of understanding its inexhaustibility and of the possibility of its application in accordance with the specifics of knowledge - humanitarian, natural, or technical; b) procedural deployment (dialogue, polemics, polygon) with the prospect of achieving the result of scientific research (truth, compromise, balance of interests, harmony, mutual exclusion of points of view, etc); c) the unity of rational substantiation of a thesis and its emotional expression.

The above requirements are of particular importance for the legal science, which operates, as it is commonly known, the notion of «norm», proceeds from the importance of its meaningful definition as a means: a) of observance / achievement of the balance of interests of various social groups, individuals, private and legal entities, etc.; b) of finding a dynamic balance of interaction of the main spheres of legal reality (say, legal regulation of information security and ensuring freedom of speech); c) of the normalization of relations of interpersonal interaction (legal regulation of human and civil rights and freedoms); d) of legal reformation of the Center's and regions' relations, of the activities of united territorial communities, of decentralization of management (optimal filling the state

\footnotetext{
${ }^{7}$ Петренко Е. Л. Критический рационализм // Политическая энциклопедия. В 2-х т. Т.1 / Нац. обществ.-науч. фонд; Рук. проекта Г. Ю. Семигин; Науч.-ред. совет: пред. совета Г. Ю. Семигин. М.: Мысль, 2000. 750 с.
} 
budget, the state target funds, and the budgets of united territorial communities, formation of an effective mechanism of tax assistance for the development of small and medium entrepreneurship, etc); e) of the establishment of international legal principles of positioning of Ukraine in the European and world space. The domestic system of constitutional law offers, as it is known, solid groundwork in terms of theoretical and methodological, legal and regulatory, and institutional search for satisfactory answers to the challenges of the sovereign development of Ukraine, including in terms of comprehension of the above problems ${ }^{8}$.

The theoretical and methodological potential of critical thinking gives answers, based on the text of the Constitution of Ukraine, in terms of, in particular, the expediency of reaching compromises and agreements, for example, with opponents of Ukrainian statehood, opponents of the sovereign development of the Ukrainian state, proponents of its consideration as «an accidental formation», «a weak state,» «a semistate,» etc. For example, when resolving the issues of territorial integrity and sovereign development of Ukraine, of its annexed and occupied territories, it is obvious that compromises are impossible on the following issues: a) granting a special status to the quasi-state formation of the Individual Regions of the Donetsk and Luhansk oblasts; b) conducting elections in the annexed and occupied territories; c) the formation of law enforcement agencies from among the local population; d) the inadmissibility of separating the occupied territories from the «body» of Ukraine. In this case, the theoretical and legal basis for the consideration and solution of the above-mentioned issues is, of course, international law, in particular, law of armed conflict ${ }^{9}$.

Accordingly, the tasks of scientific criticism are seen in the establishment of the truth in science, of the truth in society («truth as the meaning of life», A. de Saint-Exupery), in the positioning and constructing by a subject of activity of social space, the formation of tolerant principles of life of society through the establishment of its openness, preventing / overcoming the language of confrontation and hatred, manipulating individual and collective consciousness, in particular, as leitmotivs of the recent presidential campaign in Ukraine, etc.

\footnotetext{
${ }^{8}$ Федоренко В. Л. Система конституційного права України: теоретико-методологічні аспекти : монографія. К.: Ліра-К, 2009. 580 с.

${ }^{9}$ Тимченко Л. Д., Кононенко В. П. Міжнародне право : підручник. К.: Знання, 2012. 631 с.
} 
Critical thinking can be considered as a source of supplying scientific knowledge, empirical information for reflection and systematic actions, generalizing conclusions and also as an indicator of the social health of a nation. Accordingly, it can be argued that the ability to correctly use the potential of critical thinking is a sign of the developed intellectual capacity of a person for communication as a form of tolerant / non-violent interaction and creative collaboration. It seems that the aforementioned capability of critical thinking unfolds as a purposeful activity in such possible areas: a) academic criticism as a scientific inquiry, the process of searching for knowledge (truth, novelty, utility, efficiency). In this case, the main forms of deployment of criticism are polemics, discussion, dialogue, and polylogue, which are carried out in accordance with established paradigms of scientific knowledge with the use of appropriate methodological tools (immanent criticism, epistemological and factual criticism), etc; b) civil dialogue as a means of achieving social compromise, peace and accord, conclusion of possible agreements between the parties (preventing / avoiding the «language of confrontation and hostility» among different groups of the political class, «mediation» in corporate law), etc; c) public discussion (discussion of topical issues of the life of united territorial communities as a means of forming the principles of self-organization - civil, social, legal, territorial ones, definition of the strategy of local and regional development in accordance with the provisions of law of local self-government), etc; d) public political-legal dialogue (discussion of programs of presidential candidates, candidates for deputies of different levels as a means of establishing constructive interaction between citizens and their elected representatives, the rule of law and civil society on the basis of the definition / observance of the system of checks and balances, the prospects for social changes and for the achievement of common good).

Election campaigns in Ukraine, both presidential and parliamentary ones, indicate that criticism is a powerful social, political-legal, and propaganda tool for influencing large groups of people, their behavior, and electoral choices. At the same time, election campaigns are sometimes predominantly emotional, based on promises, scandals, sensations, and investigations, show events, where the flow of information rather than the spread of knowledge dominates. The dominant social background is the confrontation of discourse, meanings, content, the fight 
of «all against all»: it is usually difficult or even impossible to understand the essence of the problem that is being discussed publicly. Accordingly, the purpose of such measures is to form a «confused person» as an opposition to a «competent person».

It is obvious that the latest election campaigns in Ukraine indulge interests of the mass society with its inertness, passivity, individualism, and do not unfold, say, in accordance with the comprehended national interests, the priorities of the process of social change, ensuring the unity of the state and society, the authorities and the people, the formation of a civil identity. Information flows supplant knowledge, truth to the periphery of the public space. Dialogue as a public form of constructive interaction between parties gives way to monologue with its language of confrontation, hostility, and hatred, suspicion and distrust, the spread of stereotypes and clichés, «labels,» the widespread use of the techniques of «deceit,» «misleading rhetoric,» unwarranted promises, bribery of voters, etc.

Hence, the credo of monologue can be reduced to the postulate «he who indulges sentiments of mass society wins!», which gives rise to permissiveness, irresponsibility, legal vacuum and impunity, and, as a consequence, the irresponsibility of the elected.

Instead, the signs of criticism as a phenomenon of science and an attribute of civil society are: openness, constructiveness, goodwill, polysubjectivity, non-personality, procedurality, dynamism, goal orientation, efficiency, unity of the rational and the emotional, verity in science and truth in society.

Essential variants of criticism include: a) paradigmatic criticism; b) polyparadigmal one; c) systemic one; d) interdisciplinary (discursive) one; e) ironic one; f) satirical one; g) admiring-contemplative one; h) skeptical-negative one; i) nihilistic-destructive one.

Criteria for expediency of critical reaction as a public rationalemotional action are determined by: a) the status of a subject of criticism; b) the content of the expressed ideas, judgments, assessments and their social / practical significance / public response; c) possible results of public communication.

Criticism cannot be considered constructive in case of: a) the domination of the emotional component over the rational one; b) the absence of a scientific or socially significant subject of dialogue or polemics; c) the absence of the subject of communication. 
A subject (bearer) of criticism is a person (scientist, citizen, politician, etc), a society (an open one, a closed one), a state (a democratic one, a totalitarian one), a political nation, ideologies (left, right, and center ones) and their authorized representatives, public organizations, private and legal entities, etc.

It is generally believed that the determining ethnic-national structure of the critically minded Ukrainian society and, accordingly, the main subject / carrier of criticism in its constructive sense - meaningful, functional, and purposeful - is the formed political nation whose institutionalization activity (as one of a subject of criticism) allows, on the one hand, to render impossible the need to turn to populism as well as to eliminate the current practice of forming «parties and blocs of the named after...», and, on the other hand, to guarantee the ideological certainty of political parties and blocs as a reflection of legitimate interests and expectations of citizens, of the people of Ukraine.

Accordingly, there are grounds to argue that civil reflexive and behavioral criticism is the determining basis for the formation of the value consent of different social classes and groups which is based on national interests as a reflection of the civil stance of the inhabitants of Ukraine.

The object of criticism is represented by publicly expressed ideas, judgments, views, assessments, theories, concepts, normative legal acts as well as socially high-profile actions, etc. Criticism under all circumstances should be meaningful, substantiated, effective in terms of proving or refuting the thesis as an object of criticism; it should never be «personal,» manipulative, emotional, built on substitution of the thesis or arguments, on subjective interpretation of the basic premise of polemics, etc.

Critical analysis of the results of several sociological studies of the Institute of Sociology of the National Academy of Sciences of Ukraine obtained during the presidential election campaign shows that the desired ideological foundation for constructive interaction of the participants in the election race is associated with three basic ideological platforms as an integrative model of Ukraine's development:

a) parties of conservative orientation (national-democratic parties based on the model of the People's Movement of Ukraine of the 90-ies of the last century);

b) parties of left and centrist orientation (social democratic parties in the European sense); 
c) parties, whose activities are associated with Christian-democratic ideas (the Autocephalous Local Orthodox Church of Ukraine as a reflection of the spiritual aspect of sovereign development).

It is significant that the representatives of the domestic political class did not use the opportunity to form a new ideological synthesis as a consolidated platform for determining the strategic prospect of Ukraine's development. This means that the competitiveness of the domestic electoral system does not ensure the systemic integrity of the politicallegal space in terms of the interaction of its components, the integration of society: national interests, political ideologies are replaced by party or personal / clan interests. Political competition is all-triumphant, because it not only kills the ability to think critically, at least in terms of comprehension of national interests and understanding the prospect of social change, but also sacrifices the consolidation potential of the Ukrainian nation.

Similarly, critical thinking, based on the results of recent sociological research, allows us to state: liberal ideologies and respective parties are marginal in Ukraine, since they, lacking a constructive program of their own actions and electoral support, are oriented primarily to serve the interests of actors of political and legal action not characteristic for them, first of all, of representatives of oligarchic capital, financial and industrial groups, etc.

Established positions, outdated paradigms proceeding from the need to find out and solve contradictions by means of overcoming (eliminating) one or even both parties of the relationship between entities not only have lost their effectiveness, scientific expediency, but also become a direct path to possible social upheavals, including world cataclysms.

The modern method of solving the most important contradictions of the modern world is associated with attempts to find, even between opposite, mutually exclusive theoretical constructs, common points of contact, elements of their unconditional focus on social good, harmony, understanding, etc. This means that modern humanitarian science should master multidisciplinary approaches, non-traditional means, methods, ways, and techniques for analyzing social phenomena, weighed, tolerant attitudes toward different philosophical systems and their authors, developing a peculiar methodology of constructive critical thinking, conducting a civilized dialogue between representatives of the classical, 
non-classical and post-classical science, supporters of different ideological and political orientations in terms of reaching a consensus, civil accord, of avoiding confrontation, and so on. After all, only joint actions can help choose a civilized option for clarifying the problems of dialogue and polemics, creating of modern global technologies built on universal human development priorities. On the other hand, these same forces (or even one of them, if it slips out of democratic social control) can disrupt the balance, turn from a constructive factor into a crisis or a destructive, destabilizing, conflict one.

\section{Faultfinding as a Phenomenon Incompatible with Scientific Criticism: Essence and Signs}

In scientific literature, faultfinding is defined as a general philosophical methodological approach, according to which: a) the search and refutation of scientific theories is carried out through formal-logical operations $^{10}$; b) the technique of polemics, which, in its essence, functions, and purpose is the opposite of scientific criticism, mainly boils down to the exchange of «arguments» using offensive terms, phrases, etc. Often, it grows into a dispute, conflict, and even confrontation of the parties, which has nothing to do with purpose-oriented activity (verity), truth, social justice, legality, tolerance. Faultfinding cultivates language of hatred and confrontation that are fairly identified as a threat to the democratic process of social change.

The main features of faultfinding are: personality-subjectivist orientation; negativity and destructiveness, closeness to creative polemics and discussions; toxicity in relation to the perception of another point of view or constructive position of the opponent, any subject of social action, which gives rise to a «deadlock» situation with an indefinite prospect of interaction between the parties as participants in polemics. It is known that A. Schopenhauer substantiated a number of sophistry techniques that have nothing to do with creative competitiveness of parties as participants in a discussion or polemic, with seeking truth, or trying to establish good, truth, and justice in society ${ }^{11}$.

Tools of faultfinding, its methodical basis and technological and informational means of influencing human consciousness include, in

\footnotetext{
${ }^{10}$ Савельева И. М. Критицизм // Политическая энциклопедия. В 2-х т. Т.1 / Нац. обществ.-науч. фонд; Рук. проекта Г. Ю. Семигин; Науч.-ред. совет: пред. совета Г. Ю. Семигин. М.: Мысль, 2000. 750 с.

${ }^{11}$ Шопенгауэр А. Эристика, или искусство побеждать в споре. СПб.: 1900.
} 
particular, methods of latent violation of the laws of thought - the laws of identity, consistency, substitution of subtle rhetoric and phrase-mongering in the process of proofing for the thesis, justification of the thesis with false arguments or arguments that themselves need proof, erroneous generalization, the use of «figures of suppression», etc. Another component of the aforementioned toolkit is represented by methods of suggestion (addressing human feelings) - «labeling», «brilliant uncertainty», «vulgarity», «unfair shuffling», «double standards», eclecticism and sophistry ${ }^{12}$.

Faultfinding forms language of hatred, the atmosphere of confrontation, lines of division - imaginary or real - of a single social and legal space in separate territories that make it impossible to form a country as a holistic phenomenon, as a sovereign constitutional and legal formation.

Propaganda is a kind of faultfinding, too; its distinctive features are: a) directness; b) lack of sources of reference; c) emotionality; d) radicalization of rhetoric.

The priority areas of the deployment of critical thinking in the domestic political and legal space include: a) clarification of the essence and potential of public interest as a means of normalizing social relations; b) substantiation of the content of the interests of Ukrainian society, of its possibilities of influencing the activity of state authorities and united territorial communities; c) definition of the essence and appointment of national interests as the theoretical and methodological basis of legal science and a means of legal and regulatory framework of social relations.

\section{Evolutionary Metamorphoses of Critical Thinking as a Kind of Indicator of the Process of the Formation of a Political Nation and the Formation of a Civil Society in Ukraine}

Critical thinking, being an attributive feature of the life of Ukrainian society, of the process of its changes, implements its content and functional potential in its following main varieties:

1. Criticism as an event: the reflection of the current state of episodic, though sometimes rather effective, use of criticism as a constructive

\footnotetext{
12 Недюха М.П. Системний аналіз історичних типів європейської ідеології. Ірпінь: Академія державної податкової служби України, 2001.195 с.
} 
means of public polemics (journalistic investigations, separate theses of public debates of presidential candidates), etc;

2. Criticism as an attribute of the educational and academic environment, of the daily life of civil society: a) the use of polemical techniques as a constructive means of developing a dialogue, a discussion - mainly in the scientific and political spheres of activity; b) the introduction of critical thinking as a constructive tool for conducting dialogue, polemics, and discussion, as well as for the definition of initial theoretical and methodological positions in terms of providing methodology, methods, and technology for the exchange of ideas (paradigms of scientific knowledge, system analysis, legal / constitutional ideology, etc.); c) a component of reforming the Ukrainian society, of the goal-oriented process of deploying social change; d) an indicator of the effectiveness of the process of the formation of a political nation and civil society in Ukraine.

3. Criticism as a social phenomenon is considered as a means, resource, and potential of changes in the everyday life of a political nation, of the formation of a civil society as well as of the formation of a separate person as an active representative of civil society.

For deployment of criticism, for its use as a tool for dialogue and polemics in public space (including virtual one), its social context is important, in particular, preserving in the Ukrainian society the social tendency of recent years - reducing the index of social cynicism, which finds its embodiment in establishing a dialogue between the authorities and the people on the issues, in particular, of «weaknesses» of social reformation.

It is significant that the effect of this tendency is accompanied by the formation of the desirable state of a «generation leap»: older generations should not impose their values on young people, since the latter are characterized by pro-market value orientation and purpose-oriented action, built on personal interest. With the aforementioned tendency, in particular, the hopes of the formation of the desired image of the future Ukraine as a European state are associated. 


\section{Threats to the Spread of Critical Thinking in Ukrainian Society}

As analysis shows, the main challenges and dangers of the establishment of critical thinking in Ukrainian society include the following ones:

a) the spread of post-truth, falsehood, and imitation as the basis for the formation of a society of mistrust, an environment of violence, «a war of all against all,» language of hatred, which creates threats to sovereign development of the Ukrainian state;

b) the formation of a «confused person» as a person-mass, who has lost himself, his ability to think critically, to adequately assess sociopolitical situation, since he is not up to speed on information flows nor does he trust sources of information and the authorities;

c) conscious focus on a «confused person», a «man of the masses» as a means of achieving a guaranteed victory;

d) populist statements (promises, slogans, declarations, emotionally oriented appeals, etc) as a threat of the revanche of anti-Ukrainian forces.

Constructive criticism is able to help overcome the wall of alienation between the authorities and the people by establishing a dialogue between the authorities, the public, and the entrepreneurs, the establishment of the Ukrainian language as a means of forming a single social space, a mandatory attribute of state building, of the educational process, of the self-actualization of a person. That is, a united and indivisible country should be built, the foundation of which should be represented by legal (constitutional) ideology ${ }^{13}$.

Scientific criticism as the ideological and theoretical (worldview, value) basis of sovereign development, of ensuring the integrity of the country as well as a theoretical and legal means of responding to the ideology of the «Russian world» involves the presence of: a) a political ideology of national-democratic orientation; b) a legal (constitutional) ideology; c) a variant, adapted to the domestic realities, of one of the globalist ideologies - liberalism, conservatism, or social democracy; d) the political ideology of a «new synthesis»- in accordance with the national interests comprehended and standardized by law.

Identification signs of constructive criticism are represented by the degree of the establishment of verity in science and truth in society. Accordingly, scientific criticism by its nature, status, and purpose should

\footnotetext{
${ }^{13}$ Недюха М.П. Правова ідеологія українського суспільства : монографія. К.: “МП “Леся”, 2012. 400 с.
} 
be considered as an effective means of establishing a dialogue between the authorities and the people, ensuring transparency of the authorities, countering the formation of the atmosphere of hatred and confrontation in society, avoiding stereotyping of public opinion, preventing manipulation of human consciousness as well as promoting the orientation of media to unbiased, objective coverage of events and facts.

The means of achieving truth include, above all, the established paradigms of scientific knowledge (Marxism, structural functionalism, conflictology, the theory of social action, ethno-methodology, etc.), nonclassical and post-classical theoretical and methodological approaches, which are also associated with the positioning and construction of the social / legal space of a subject of social action.

The real threats to verity in science - as a constructive means of polemics - include: a) discourse; b) an uncritical combination of theoretical and methodological propositions of various intellectual traditions, say, of structural functionalism and synergetics, of Marxism and the structural-functional approach, of Marxism and conflictology, etc, which leads to an eclectic combination of mutually exclusive propositions, conclusions, and recommendations; c) attempts to artificially indoctrinate into public opinion through media an atmosphere of contempt, intolerance, anger, hatred ${ }^{14}$, artificial lines of confrontation ${ }^{15}$, and so on.

The recent presidential election campaign in Ukraine has confirmed the rightness and scientific correctness, albeit with a delay of almost three years, of the proposal of the Oxford Dictionary of the English Language to consider the word of 2016 to be «post-truth» as a generalized description of the circumstances, the socio-political situation that has developed in a country, where objective facts influence the formation of public opinion less than emotions or personal beliefs, usually subjective, as well as mass propaganda shows.

Ignoring the identification potential of truth in Ukrainian society on the part of media does not allow to initiate a dialogue between the authorities and the people, the country of laws and civil society, much less to transform it into a nation-wide polylogue (as variants: a citizen - the

\footnotetext{
14 Опубліковано на веб-сайті https://zik.ua/news/2019/02/01/stavniychuk_rozkrytykuvala_ predstavnykiv_vlady_yaki_vyyshly_z_studii_narod_1501273

15 Громадянська активність в Україні: чи приречені ми мати те, що маємо // URL: https://dt.ua/POLITICS/gromadyanska_aktivnist_v_ukrayini_chi_prirecheni_mi_mati_te,_scho_maemo.html
} 
authorities - the people, the state - the public - the small and medium entrepreneurs) on the basis of consensus principles of cooperation, tolerance, social compromise, and civil peace.

Accordingly, the main threats to the truth as an identifying feature of an open society include: a) manipulation of public opinion, its stereotyping; b) the establishment in society of an atmosphere of confrontation, intolerance and cruelty, incitement to hatred and violence; c) the absence of legally regulated practice of responding to foreignpolicy and ideological massive aggression by individual neighboring countries. Tellingly, the results of sociological research that are manipulatively obtained and subjectively interpreted «for a candidate» often turn into agitation, a tactical means of conducting an election campaign $^{16}$.

On the basis of active participation in the electoral process, of the attitude toward the presidential programs of the candidates for presidency in Ukraine, the adult population can be divided into two large groups of approximately equal numbers of voters - critical thinking supporters and «criticism» fans. This conclusion is encouraged by several circumstances: a) the election campaign did not answer the question of the desirable image of Ukraine in the consciousness of its citizens, which suggests that none of the candidates has offered any holistic vision of the process of social change, according, say, to the provisions of Art. 1 of the Constitution of Ukraine; b) the public nation-wide pre-election discussion did not allow to make it to a systematic vision of the prospect of Ukraine becoming a legal, democratic, social state; c) the public discourse of the discussion of the programs showed the dominance of technological aspects of the participation of a particular candidate in the election process, rather than discussing the content components of the program in their compliance with the challenges of Ukraine's sovereign development, etc.

\section{CONCLUSIONS}

1. Critical thinking can be considered one of the key competencies of man, taking into account, in particular, a number of features inherent in it: a) constructiveness; b) dialogicity; c) the ability to distinguish truth from error, truth from post-truth; d) providing legitimate protection against deception and manipulations that are disseminated by mass media;

\footnotetext{
16 Опубліковано на веб-сайті https://zik.ua/news/2019/02/01/stavniychuk_rozkrytykuvala_ predstavnykiv_vlady_yaki_vyyshly_z_studii_narod_1501273
} 
e) establishing the truth about Ukraine and its people, its past, present, and future.

2. The potential of critical thinking, its social and political-legal effectiveness is determined by the degree of maturity of a political nation / civil society as the subject of criticism. According to recent sociological surveys, only $7 \%$ of Ukraine's population holds an active civic position; $80 \%$ of Ukrainian citizens do not engage in social activities at all; $53 \%$ do not have a developed sense of responsibility, in particular, for the state of the situation in the country: a culture characteristic of subjects forms, as it is known, paternalistic mass consciousness and social reconciliation.

3. Priority areas for the deployment of critical thinking are: a) clarification of the essence and potential of public interest as a means of normalizing social relations; b) substantiation of the essence of the interests of various social groups of Ukrainian society, their possibilities of influence on the activities of state authorities and local self-government bodies; c) definition of the essence and purpose of national interests as a theoretical and methodological basis of legal science and a means of legal regulation of social relations, etc.

4. Constructive criticism should be considered as an effective means of counteracting the formation of an atmosphere of hatred and confrontation in society, of avoiding stereotyping of public opinion, manipulation of human consciousness as well as promoting the orientation of mass media to objective coverage of events and facts, of ensuring human and civil rights and freedoms, transparency of power, and of establishing a dialogue between the authorities and the people.

5. Constructive criticism as an ideological and theoretical (ideological, value) component of sovereign development as well as the theoretical and legal basis for responding to the ideology of the «Russian world» implies the presence of: a) a political ideology of the nationaldemocratic orientation; b) a legal (constitutional) ideology; c) an variant of one of the globalist ideologies - liberalism, conservatism, or social democracy - adapted to domestic realities; d) the political ideology of a «new synthesis» - in accordance with the national interests comprehended and standardized by law.

6. It is unacceptable to identify critical thinking with formal-logical thinking, much less to reduce criticism to correcting mistakes made, for example, in a scientific text. Critical thinking has nothing to do with faultfinding as a biased subjectivist position, the mental set of rejecting a 
stand taken, an author's view declared, a particular judgment or argument as allegedly a priori ineffective.

7. Critical thinking takes on characteristics of professional competence and professional formation of graduates with bachelor's and master's degrees. Accordingly, there are grounds to state that it is advisable to introduce a student course with the tentative working name «Critical Thinking as a Paradigm of Scientific Research.»

An urgent task is, in our view, to substantiate the theoretical and constitutional and legal principles of scientific criticism as a constructive means of ensuring the unity of science and education in the educational process, to form critical thinking as a professional competence, substantially limiting / overcoming the practice of political and legal manipulation of individual and mass consciousness, which implies unconditional reneging on the previous tradition of all-consuming influence of the state on a individual, society as a whole and establishing the priority of human and citizen rights, considering man as the highest social value.

Important tasks are also connected with the possibilities of introducing critical thinking into the educational process in terms of forming in students skills and abilities to tolerantly conduct dialogue, public polemics, correctly pose questions and give satisfactory answers to them, etc, which will facilitate the humanization of the domestic social space, the establishment of a consensus basis of society's life. Critical thinking should acquire the signs of professional competence and professional development of undergraduates and graduate students. Accordingly, there are grounds to state that it is advisable to introduce a student course with the tentative working name "Critical Thinking as a Paradigm of Scientific Research.»

In the educational process, it is important to emphasize that, for example, domestic mass media often resort to a manipulative technique, the name of which is "primitive reductionism»: they identify petty, administrative, and political corruption, reducing them to petty one. In this case, the helplessness of the authorities in confronting corruption often goes down to the generalizing constant: «Corruption is invincible, because the people are so!», that is, as it happens, the Ukrainian people engender corruption by definition. Corruption is presented as a sort of a birthmark of a Ukrainian citizen, allegedly a daily and long-time attribute of his life.

At the same time, the results of applying the methodology of critical thinking show: a) the greatest threat among the above-mentioned types of 
corruption is, of course, political corruption, which, becoming a threat of a nation-wide nature, is quite rightly connected mainly with the activity of the bureaucratic apparatus of central executive and local government bodies; b) the people cannot be a bearer of corruption because of a number of circumstances: they de facto are some of the poorest in Europe and de jure a source, a bearer of power, of the sovereignty and independence of the country. Accordingly, a simplified, primitive, preWeberian (XIX century) understanding of corruption is imposed upon society.

8. The uniqueness of critical thinking lies in the fact that unfolding as a monologue, dialogue, or a polylogue, the specified social phenomenon always involves an interlocutor, imaginary or real. It is also unique in its results: verity, truth, responsibility, rights and freedoms, honor and conscience. Criticism and plagiarism are incompatible in nature. There are no doubts concerning public achievements of critical thinking, either: a self-sufficient personality, a formed political nation, a humanized social space, civic consensus as a counterweight to cynicism and disappointment, post-truth, bureaucracy, and corruption, the omnipotence of the Golden Calf. Legal critical thinking, in accordance with the realized national interests, forms the modern Ukrainian political nation as a unique natural creature and an irresistible social phenomenon of the world history.

9. Critical thinking, in its essence and functionality responding to the European tradition of the rule of law, contributes to the strengthening of domestic constitutionalism, inter alia, concerning the ensuring of rights and freedoms of man and citizen (forms and methods, guarantees, implementation mechanism), and creates conditions for civil society to control actions of the state and its authorized persons.

\section{SUMMARY}

The essence and purpose of scientific criticism / critical thinking as an effective toolkit of science and a social phenomenon of civil society are substantiated. Its subjective and objective components, sources, characteristic features and tasks as well as priority areas of deployment of scientific criticism and variants of the latter are described. Identification signs of scientific criticism in science and society are identified, being, respectively, verity and truth. The evolutionary dependence of the content and functional characteristics of critical thinking on the dynamics of the process of social change, the formation of civil society in Ukraine is 
analyzed. Faultfinding as a phenomenon incompatible with scientific criticism is considered. Emphasis is laid on challenges and threats, objective and subjective obstacles to the spread of critical thinking in the Ukrainian society.

\section{REFERENCES}

1. Недюха М. П. Критика як теоретико-пізнавальний та діалогово-полемічний конструкт конституційно-правового мислення // II Всеукраїнські правові наукові читання пам'яті доктора юридичних наук, професора, заслуженого юриста України, членкореспондента Національної академії правових наук України Ніни Романівни Нижник: збірник матеріалів / за заг. ред. А. Є. Шевченка. Вінниця: ТОВ “ТВОРИ”, 2018. 180 с.

2. Лебедев С. А. Философия науки : краткая энциклопедия (основные направления, концепции, категории). М.: Академический проект, 2008. 692 с.

3. Шопенгауэр А. Эристика, или искусство побеждать в споре. СПб.: 1900.

4. Асмус В. Ф. Иммануил Кант. М.: "Наука”, 1973. 534 с.

5. Бернштейн Э. Воспоминания: Социал-демократические годы учения. В годы моего изгнания. К.: Основні цінності, 2005. 328 с.

6. Поппер Карл. Открытое общество и его враги. Т.1: Чары Платона. Пер. с англ. под ред. В. Н. Садовского. М.: Феникс, Международный фонд “Культурная инициатива", 1992. 448 с.; Т. 2: Время лжепророков: Гегель, Маркс и другие оракулы. М.: Феникс, Международный фонд “Культурная инициатива”, 1992. 528 с.

7. Петренко Е. Л. Критический рационализм // Политическая энциклопедия. В 2-х т. Т.1 / Нац. обществ.-науч. фонд; Рук. проекта Г. Ю. Семигин; Науч.-ред. совет: пред. совета Г. Ю. Семигин. М.: Мысль, 2000. 750 с.

8. Федоренко В. Л. Система конституційного права України: теоретико-методологічні аспекти : монографія. К.: Ліра-К, 2009. 580 с.

9. Тимченко Л. Д., Кононенко В. П. Міжнародне право : підручник. К.: Знання, 2012. $631 \mathrm{c.}$

10. Савельева И. М. Критицизм // Политическая энциклопедия. В 2-х т. Т.1 / Нац. обществ.-науч. фонд; Рук. проекта Г. Ю. Семигин; Науч.-ред. совет: пред. совета Г. Ю. Семигин. М.: Мысль, 2000. 750 с. 
11. Недюха М.П. Системний аналіз історичних типів європейської ідеології. Ірпінь: Академія державної податкової служби України, 2001.195 с.

12. Недюха М.П. Правова ідеологія українського суспільства : монографія. К.: “МП “Леся”, 2012. 400 с.

13. Опубліковано на веб-сайті https://zik.ua/news/2019/02/01/ stavniychuk_rozkrytykuvala_predstavnykiv_vlady_yaki_vyyshly_z_studii _narod_1501273

14. Опубліковано на веб-сайті https://gordonua. com/ news/ politics /portnikov-ukrainskie-patrioty-vedut-sebya-tak-budto-vneshnego vraga-iego-vnutrennego-soyuznika-bolshe-net-663786.html

15. Громадянська активність в Україні: чи приречені ми мати те, що маємо // URL: https://dt.ua/POLITICS/gromadyanska_aktivnist_v _ukrayini_chi_prirecheni_mi_mati_te,_scho_maemo.html

Nediukha M. P.

Doctor of Philosophic Science, Doctor of Science of Law, Professor, Professor of the Chair of Constitutional and International Law of the V. I. Vernadsky Taurida National University 33, Ivan Kudria str., Kyiv, Ukraine nngi@tnu.edu.ua 